\title{
原著
}

めまいが初発症状となった原始三叉動脈遺残症例

土井 彰1)・田村 耕三1) - 小桜 謙一1) - 福井 直樹2

\section{A case of Parsistent primitive trigeminal artery}

with vertigo as the initial symptom

\author{
Akira Doi ${ }^{1)}$, Kozo Tamura ${ }^{1)}$, Kenichi Kozakura' ${ }^{1)}$, Naoki Fukui ${ }^{2)}$ \\ ${ }^{1)}$ Division of Otolaryngology, Kochi Health Sciences Center \\ ${ }^{2}$ Division of Neurosurgery, Kochi Health Sciences Center
}

A case of persistent primitive trigeminal artery with vertigo as the initial symptom is reported. The case was a 41 -year-old female. Since 2002 , the patient had repeated episodes of vertigo. In 2004, the patient experienced a loss of consciousness. No lesion causing dizziness was found by CT scan of the brain, MRI of the brain, ECG, brain wave examination, and a balance function test at the Department of Otolaryngology. Persistent primitive trigeminal artery and vertebrobasilar hypoplasia were suspected by MRA and the diagnosis was confirmed by angiography. It is advisable to consider MRA and angiography for vertigo or dizziness of unknown cause.

Key words: persistent primitive trigeminal artery, vertigo, initial symptom

はじめに

内頸動脈と脳底動脈を結ぶ胎生期の遗残動脈

（図 1）のらち，最も頻度が高いのが原始三叉動 脈であり，脳血管撮影上の頻度は0.2〜0.6\%であ る 当。通常無症状であり，合併症の精査中ある いは脳血管撮影上偶然に発見されることが多い。 合併症は脳動脈瘤が14 30\%と最も多く4)5), そ の他子やもや病 ${ }^{6}$, 脳動静脈奇形7), 内頸動脈一 海綿静脈洞瘦 ${ }^{8}$, 〈も膜下出血 ${ }^{9)}$, 脳梗塞 ${ }^{10)}{ }^{11}$ で ある。原始三攴動脈そのものに対してではなく合 併症に対する治療が施される6) 99。予後は合併症 の状態に左右される。

これまでの報告を調べる限り，原始三叉動脈遺 残の合併症である脳梗塞の経過中に，めむい発症

\footnotetext{
1) 高知医療センター耳鼻咽喉科

2) 高知医療センター脳神経外科
}

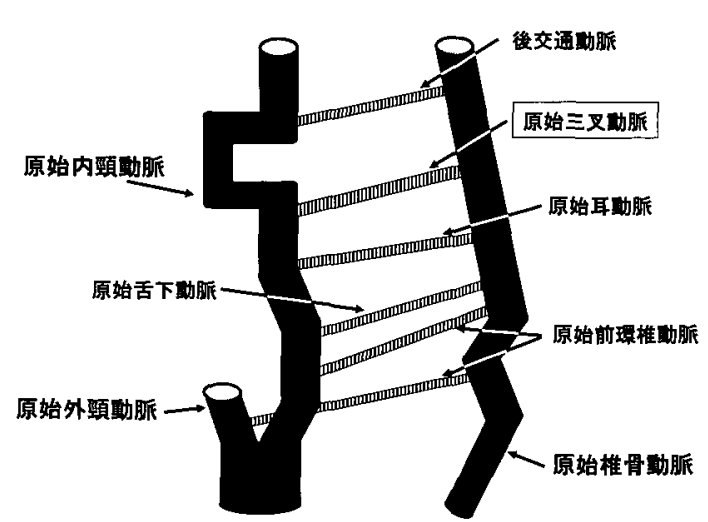

図 1 原始血管吻合模式図

胎生期（頭警長 $8 \mathrm{~mm} \sim 15 \mathrm{~mm}$ ) に発生し 消失する血管。斜線で示すごとく6 種類め る。(文献14を改変) 
の報告はある12) ものの，めまいが主症状の報告 は見当たらなかった。今回我々はめまいで発症し た原始三叉動脈症例を経験したので報告する。

\section{症例}

症例：41歳，女性

主訴：回転性めまい

既往歴: 平成 6 年 C5 椎骨へルニア

平成16年出産。出産後約 $15 \mathrm{~kg}$ の増加があり現 在に至る。

現病歴: 平成14年の秋, 入浴中に景色が右に流 れる状態が出現したが 1 時間で症状は治まった。 すぐに近くの救急病院を受診したが異常を指摘さ れなかった。翌日近医耳鼻咽喉科を受診し，メ二 エール病疑いと診断された。以後めまいは発症し なかったため通院せず放置していた。

平成16年 7 月 2 日夕方，子供をあやしていると きに右に体が傾く感じが出現したため, すぐに近 くの救急病院を受診した。また 7 月 9 日には意識 消失発作が出現し，別の救急病院を受診した。7 月 2 日，9 日の 2 日間で CT, MRI, 心電図, 脳波, 血液検査を施行されているがいずれも異常は指摘 されなかった。またいずれのめまい時にも随伴す る蝸牛症状は認めなかった。

\section{反転フィルム}

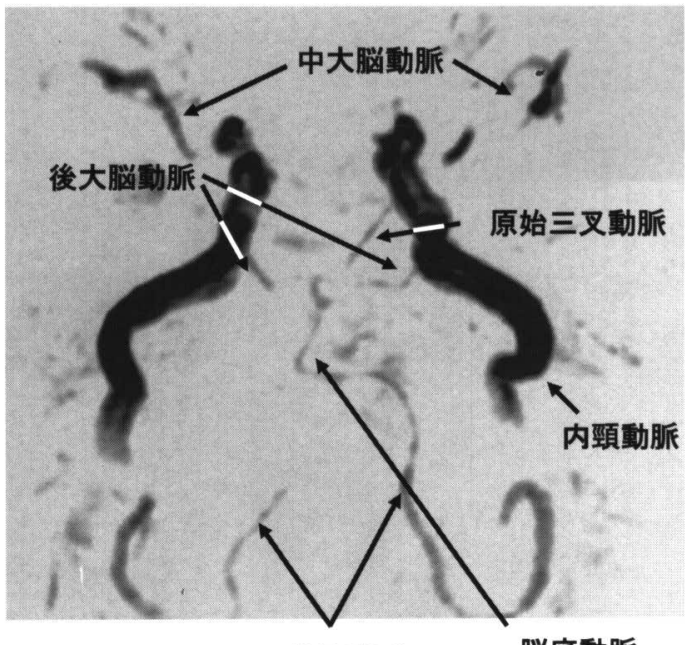

椎骨動脈
精査希望にて同年 7 月 12 日当科初診。初診時, 症状は非回転性めまい（右へ傾く感じ）のみで あった。

理学所見：

1.耳鏡検査：鼓膜正常。

2. 標準純音聴力検査 : 右 $22.5 \mathrm{~dB}$, 左 $23.8 \mathrm{~dB}$ (4 分法), 左 C-5dip 型

3. 平衡機能検査 :

足踏又検査, 遮眼書字検査, 重心動摇検査は異 常を認めなかった。また注視，自発，頭位・頭位 変換眼振検査で眼振を認めなかった。電気眼振図 を用いた温度刺激検査（20度，水， $5 \mathrm{ml} ， 15$ 秒間) では最大緩徐相速度右耳 $20^{\circ} /$ 秒, 左耳 $26^{\circ} /$ 秒 であった。

4.一般神経学的検査：

指鼻試験正常。二頭筋反射, 三頭筋反射に六進 認めず。ホフマン, トレムナー, ワルテンベルグ 反射は陰性。振動覚正常。シェロングテスト陰性。 他神経学的に異常所見を認めなかった。

5. 血液検査 :

一般血液検査，凝固因子，血清脂質，肝機能腎 機能，梅毒検査で異常を認めなかった。

6. 画像診断

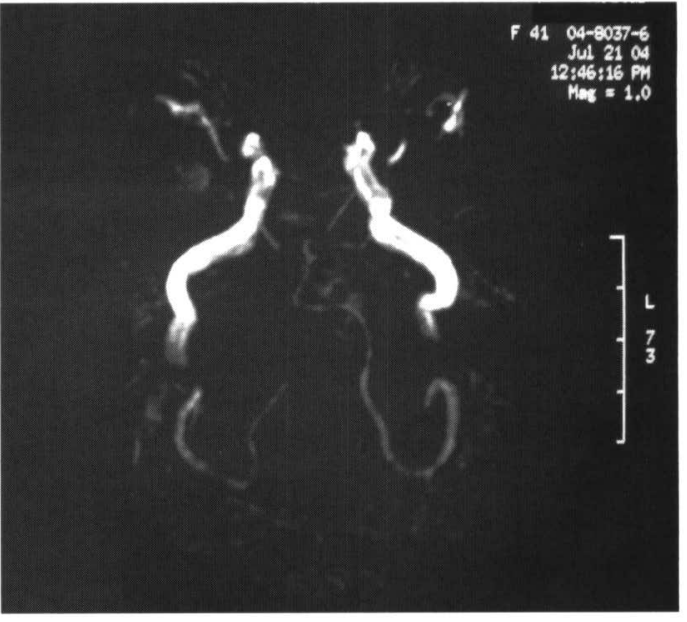

図 2 MRA 所見

実際のフィルムでは図示しらららいため反転像に血管名を示す。図では原始三叉動脈を図示しているが，こ れは血管造影の結果と照らし合わせて初めて判明した。実際にこの画像から原始三叉動脈の存在を示すこ とは困難である。 


\section{左内頸動脈}

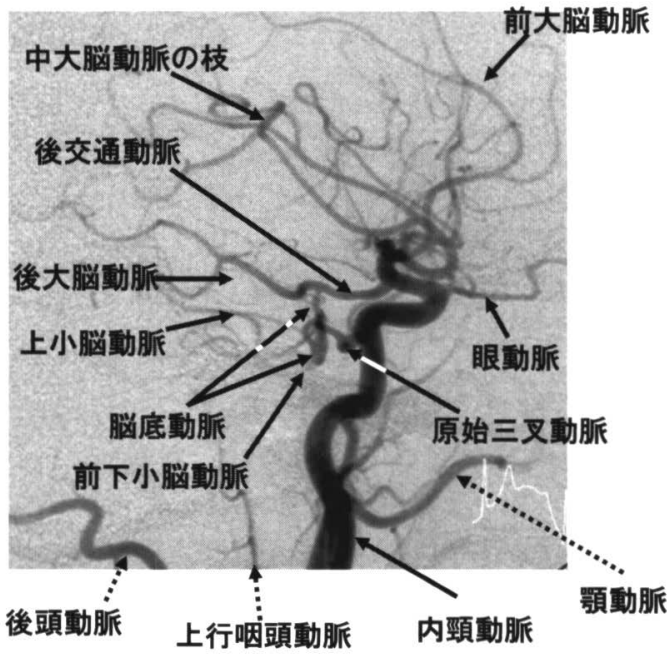

\section{右内頸動脈}

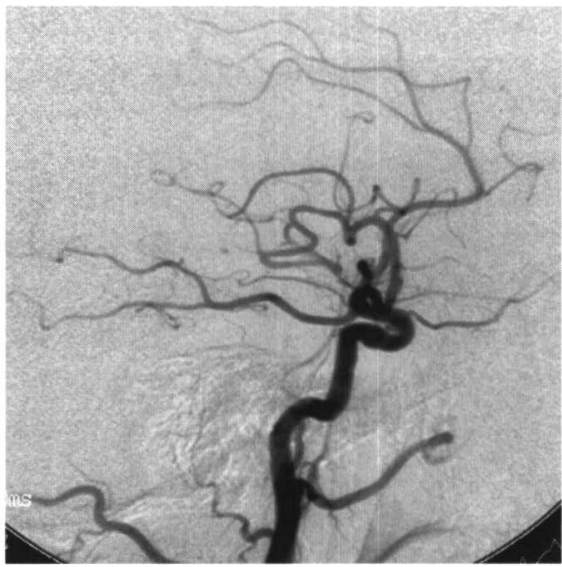

額動脈

\section{a. 内頸動脈}

\section{左椎骨動脈}

右椎骨動脈

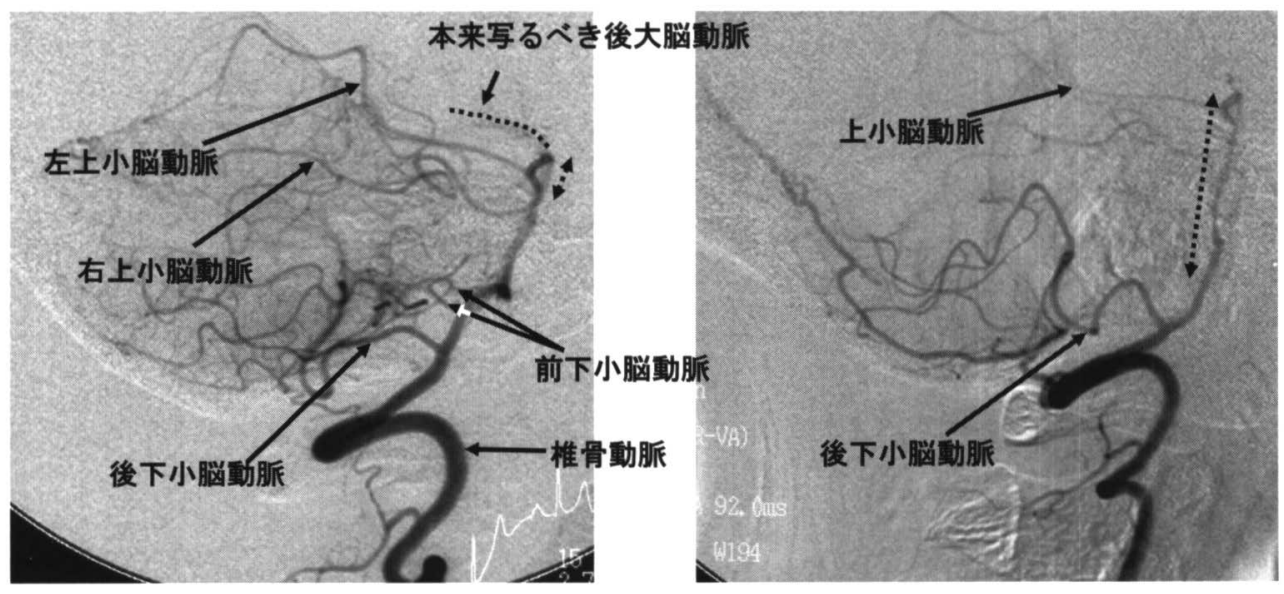

\section{b. 椎骨動脈}

図 3 血管造影所見

a は内頸動脈, b は椎骨動脈の造影である。a：原始三叉動脈との接続部から上下に血流が分かれていく。 点線矢印は外頸動脈系の血管を，実線は内頸動脈系の血管を示す。b：点線は血流の乏しい領域を示す。

MRI では慢性副鼻腔炎を認めたが，第 8 脳神 経, 小脳, 脳幹, 大脳に著変を認めなかった。 MRA（図 2 ）では右椎骨動脈低形成を認めたた め, 血管造影（図 3 ）を施行したところ, 左内頸 動脈の造影で原始三叉動脈の存在が明らかとな り，かつ上小脳動脈には原始三叉動脈からの血流
が入り込んでいた。また，椎骨動脈の造影では右 椎骨動脈が低形成かつ両側前下小脳動脈が細く, 同部位からの脳底動脈形成不全を認めた（図 4)。 経過

診断確定後, めまい症状が軽減しから頸椎へル ニアによる左手のしびれの既往もあったためメコ 

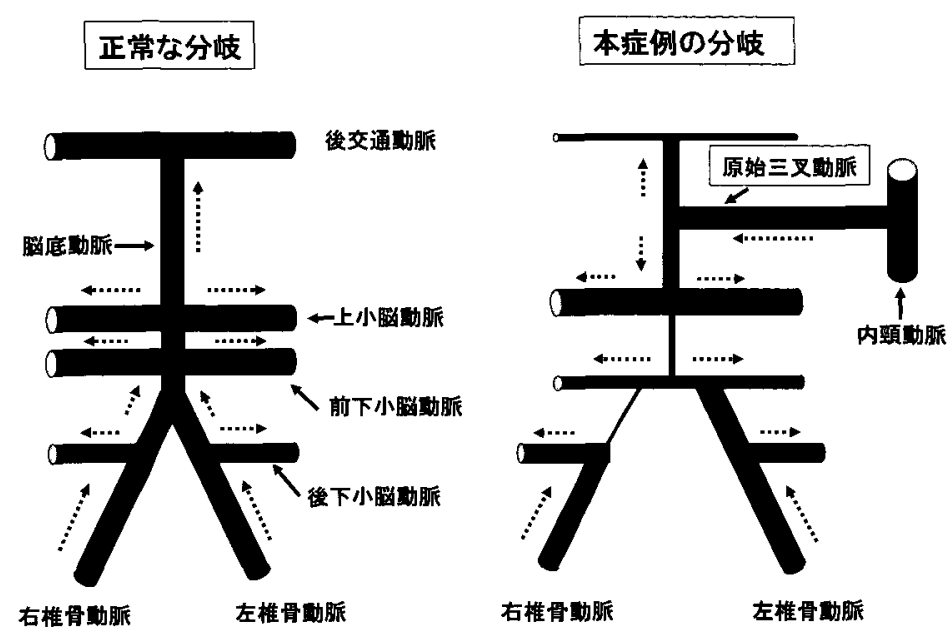

図 4 血管模式図

血管径が細いところは低形成部分で血流が乏しいところである。症例は内頸動脈から原始三攴動脈を通り 上小脳動脈に血流が走っている。点線矢印は血流の方向を示す。

バラミンを処方していた。しかし平成16年11月お よび12月に回転性めまい発作が出現し，直ちに当 科を受診した。来院時には非回転性めまいになっ ていた。これに対し炭酸水素ナトリウムを静注し たが全く効果がなかった。平成17年になりめまい 症状は再び軽減してきたので，6月上旬から仕事 復帰をしたが，まもなく回転性めまい発作が出現 するようになった。7月から塩酸ジフェニドール を発症のたびに処方しているが，副作用である口 乾燥のため定期的な服用はできていない。

な和経過中㯖力の変動は認めなかった。電気眼 振図検查は平成16年, 平成17年の 2 回施行してい るが，温度刺激検査の所見は変化していない。め まいの性質は，右に風景が流れる感じや右に体が 傾く感じが5分から30分続いた後に非回転性めま い（二日酔い，あるいは船棌った感じ）に変化 し 23 日持続している。蝸牛症状の随伴はない。

\section{考察}

1. めまいと原始三叉動脈遺残

経過中めまい発作に伴い意識消失発作が出現し ている。意識消失発作は通常, 全脳虚血あるいは 脳底動脈虚血で発生する。今回以心不全など全脳 虚血に陥る原因を認めないため椎骨脳底動脈系の 低循環，特に本症例は椎骨脳底動脈系の低形成を 伴っており，これがめまいの原因と考光る。

しかし，原始三叉動脈が閉鎖することで初めて
椎骨動脈から脳底動脈に至る血液循環が発生し正 常な発育が起こることを考えると, 本症例の椎骨 脸底動脈系の低形成は原始三叉動脈遺残が根本原 因他ならない。

2. なぜ40歳前後でめまいが初発したのか

原始三叉動脈の合併症は, 出血伴う精查過程 で発見されることが多い。調べた限り，出血を伴 5合併症の発症年齢恃，脳動静脈奇形のみ 16 30 歳と比較的若年であるのに対し15)16), もゃもや病・ 内頸動脈一海綿静脈洞瘻 - 脳動脈瘤・脳梗塞は40 歳以降に発症する傾向にある678) 11) (3317) -23)。この 事実は原始三叉動脈遺残症例では脳動静脈奇形を 除いて40歳前後で内頸動脈系あるいは椎骨脳底動 脈系の血管変化・循環動態の变化が発生すること を意味する。本症例では発症が 41 歳であり，かつ 体重増加が加わったため椎骨脳底動脈系の低循環 が生じたと考える。

3. めまいに対する治療

現時点ではめまい発作とのものに対する治療を 試みたが無効であった。そこで視点を変え, めま い発作の予防に焦点をおいた。椎骨脳底動脈領域 の血液循環をよくするため酒石酸イフェンプロジ ル, 塩酸ジフニドール内服が必要である。また， 肥満があると低酸素状態になりやすく，血管が詰 まりやすくなるため肥満のコントロール，さらに 末梢循環をよくするためにメコバラミン内服が必 
要である。本症例は意識消失発作を伴ったことが あり，椎骨脳底動脈系の TIA に準じた治療拈上 び予防が考慮される。

\section{4. 合併症汶対する対策}

我々が調べた限り，原始三叉動脈艺のるのに動 脈瘤が発生した報告20)はあるが，多くは他の脳 血管に生じている。

本症例では, 脳動脈熘, 脳出血, 脳梗塞が今後 合併症として発生する可能性がある。動脈瘤が 6 年間のららに出現した報告(3) があり本症例でも 発生する可能性があるため，血管造影または MRA Kよるチェックは $5 \sim 6$ 年毎に行う予定で ある。

また，脳出血を予防寸るためには本人にとって 最適となる血圧管理が重要と考光る。本症例の血 行動態は通常上異なり原始三叉動脈を経由して上 小脳動脈に血流が送られて扣り，この血管々のも のへ手術操作を行らことや，安易に降王剤を投与 することは脳幹への血流低下，あるいはそれに伴 ら意識消失発作を誘発するため危険であるら。本 症例では今後高血圧が出現したとき, 循環器内科 医師と相談して慎重に治療方針を決定する方針で ある。

\section{まとめ}

1.めまいで発症した原始三叉動脈遗残括よび 椎骨脳底動脈低形成症例を経験した。

2. CT MRIで異常を認めない原因不明の めまいに対しては MRA や脳血管造影検査まで考 慮する必要がある。

3.めむいに詨しては薬物療法のみならず肥満 のコントロールが大切である。

4. 合併症の予防が大切である。特に血行力学 的に脳動脈瘤が発生する可能性があるため, 定期 的に画像診断を行ら予定である。さらに脳出血を 予防するために血王のコントロールが必要であ る。

\section{文献}

1) Agnoli AL: Vascular anomalies and subarachinoid hemorrhage associated with persisting embryonic vessels. Acta Neurochir 60: 183199, 1982

2) Miyatake S, Kikuchi H, Kondoh S, et al: Treatment of a giant aneurysm of the cavernous internal carotid artery.: case report. Neurosur- gery $26: 315-319,1990$

3 ) Padget DH: The development of the cranial arteries in human embryo. Contrib Embryol 32: 205-261, 1948

4) Eadie MJ, Jamieson KG, Lennon EA: Persisting carotid-basilar anastomosis. J Neurol Sci 38: 501-511, 1964

5) George AE, Lin JP, Morantz RA: Intracranial aneurysm on a persistent primitive trigeminal artery. Case report. J Neurosurg 35: 601-604, 1971

6) Suzuki S, Morioka T, Matsushima T, et al: Moyamoya disease associated with persistent primitive trigeminal artery variant in identical twins. Surg Neurol 45: 236-240, 1996

7 ) Nakai Y, Yasuda S, Hyodo A, et al: Intratentrial arteriovenous malfomation associated with persistent primitive trigeminal artery-case report. Neural Med Chir (Tokyo) 40: 572-574, 2000

8) Cook BE Jr, Leavitt JA, Dolan JW,et al: Carotid cavernous fistula associated with persistent primitive trigeminal artery. J Neuroophtalmol 20: 264-265, 2000

9 ) Takase T, Tanabe H, Kondo A, et al: Surgically treated aneurysm of the trunk of the persistent primitive trigeminal artery. Neural Med Chir (Tokyo) 44: 420-423, 2004

10）金井秀樹, 山田和雄，小松裕明，他：頸部内 頸動脈狭窄症に出ける側副血行路として描出 された persistent primitive trigeminal artery の 1 例. 脳神経外科シャーナル 10: 475-480, 2001

11) Ito $Y$, Watanabe $H$, Niwa $H$, et al: The protective effect of a persistent trigeminal artery on brain stem infarctions: A follow-up case report. Intern Med 37: 334-337, 1998

12）織茂智之, 後藤耕作, 小沢英輔, 他: 両側椎 骨動脈低形成，右遺残原始三叉動脈を有し， 症候群から早期汇回復した若年脳梗塞の1 例. 臨床神経学 36: 993-995, 1996

13）石黒雅敬, 中川俊男, 山村明範, 他：Persistent primitive trigeminal artery に合併した脳 動脈瘤の新生. 脳神外科 23: 1017-1020, 1995 
14）中村 貢，甲村英二，西尾明正：血管解剖. 滝和郎編. 症例から学ぶ腷血管手術改訂 2 版. 67-123頁，メディ力出版，大阪，2004

15) Ohtakara K, Kuga Y, Murao K, et al: Posterior fossa arteiovenous malfomation associated with persistent primitive trigeminal artery-case report. Neurol Med Chir (Tokyo) 40: 169-172, 2000

16) Uchimo A, Matsunaga M, Ohno M: Arteriovenous malformation of the corpus callosum associated with persistent primitive trigeminal artery-case report. Neurol Med Chir (Tokyo) 29: 429-432, 1989

17）藤本基秋, 中原一郎, 田中正人, 他：神経線 維腫症 1 型に多発性脳動脈瘤, 血管奇形を合 併した 1 例. 脸神外科 32: 355-359, 2004

18）中山正基, 新納正毅, 平原一穗, 他 : persistent primitive trigeminal artery $\zeta$ metopism を合併した破裂脳動脈瘤の 1 例. 脳神外科 22: 651-655, 1994

19) Chen ST, Liu YH: Moyamoya disease associated with bilateral persistent primitive trigeminal arteries: report of a case. J Formos Med Assoc 92: $385-387,1993$

20）藤井幸彦，川崎昭一，阿部博史，他：persistent primitive trigeminal artery 本幹部動脈瘤 の 1 剖検例. 脳神外科 16: 181-186, 1988

21) Kwak R, Kadoya S: Moyamoya disease associated with persistent primitive trigeminal artery Report of two case. J Neurosurg 59: 166171,1983

22）上田 孝，呉屋朝和，木下和夫：多発性血管 奇形の 1 例 中大脳動脈空形成 primitive trigeminal artery の遺残に合併した多発脸動脈 瘤の 1 症例，脳神外科 12: 531-536, 1984

23）太田浩嗣，厳本哲矢，横田 晃：遺残性原始 三文動脈に対側頸部内頸動脈閉塞を伴った多 発性脳動脈瘤の手術例。脳神外科 32: 10451048,2004

原稿到着：平成18年 5 月17日

別刷請求先：土井 彰

干781-8555 高知市池2125-1

高知医療七ンタ一每鼻咽喉科 